\title{
PEMBERDAYAAN UNTUK MENINGKATKAN TARAF HIDUP DI KAMPUNG ADAT CIREUNDEU CIMAHI
}

\author{
10tenius Halawa, ${ }^{2}$ Sri Nurhayati, ${ }^{3}$ Siti Rochana \\ 1,2,3 IKIP Siliwangi \\ 10thenhalawa51@gmail.com, 2shrie33@yahoo.com
}

\begin{abstract}
ABSTRAK
Untuk melaksanakan pembangunan dan pemberdayaan masyarakat secara tepat, efektif dan efisien, dibutuhkan kredibilitas sumber daya manusia masyarakat dan kualitas aparatur pemerintahan yang mampu merumuskan dan memformulasikan kebijakan, di sini dibutuhkan adanya daya kebijakankebijakan dari sumber manusia pemerintah daerah yang mampu merespon persoalan masyarakat setempat. Maka dari itu, Tujuan penelitian ini adalah bertujuan untuk mendeskripsikan Program pembangunan dan pemberdayaan masyarakat di Kampung Adat Cireundeu Cimahi serta untuk memperkuat dan mengembangkan konsep dan teori yang berkaitan dengan peningkatan pendapatan masyarakat melalui program pemberdayaan. Sampel diperoleh dari wawancara pada 10 orang informan yang didukung dengan observasi serta studi dokumentasi. Hasil penelitian menunjukkan program pelatihan yang berhubungan dengan kegiatan peningkatan pengembangan usaha telah dilakukan oleh pemerintah melalui kegiatan pemberdayaan masyarakat desa. Peningkatan Pendapatan Masyarakat Melalui Program Pemberdayaan di Kampung Adat Cireundeu Cimahi dilakukan melalui berbagai program pemberdayaan yaitu kegiatan bantuan pinjaman modal usaha melalui program nasional pemberdayaan masyarakat pedesaan, pengembangan motivasi bekerja dan berusaha pelatihan serta pelatihan keterampilan usaha ekonomi.
\end{abstract}

Kata Kunci : Pemberdayaan Untuk Meningkatkan Taraf Hidup

\section{PENDAHULUAN}

Kemiskinan merupakan masalah sosial yang saling berkaitan dengan faktor lainnya seperti ekonomi, sosial dan budaya. Kemiskinan bukan hanya menjadi masalah sosial bagi negara-negara berkembang, akan tetapi negara yang sudah maju dalam bidang ekonomi. Masalah kemiskinan merupakan hal mendasar bagi bangsa Indonesia yang merupakan negara berkembang dan saling berkaitan dengan faktor-faktor lainnya. Kemiskinan merupakan cerminan dari adanya kesenjangan dalam kehidupan dan perekonomian masyarakat (Rohaeti, Mulyono, Widiastuti, Ansori, \& Samsudin, 2018).

Menurut BPS (Badan Pusat Statistik) pada bulan Maret 2018, jumlah penduduk miskin (penduduk dengan pengeluaran per kapita per bulan di bawah Garis Kemiskinan) di Indonesia mencapai 28,07 juta orang (11,37 persen), berkurang sebesar 0,52 juta orang dibandingkan dengan penduduk miskin pada September 2017 yang sebesar 28,59 juta 
orang (11,66 persen). Selama periode September 2017-Maret 2018, jumlah penduduk miskin di daerah perkotaan berkurang 0,18 juta orang (dari 10,51 juta orang pada September 2012 menjadi 10,33 juta orang pada Maret 2018), sementara di daerah perdesaan berkurang 0,35 juta orang (dari 18,09 juta orang pada September 2017 menjadi 17,74 juta orang pada Maret 2018).

Upaya peningkatan kesejahteraan masyarakat bukanlah sekedar dalam arti ekonomi (pendapatan) bagi tercukupinya sandang, pangan, dan papan tetapi mencukupi kebutuhan-kebutuhan ekonomi, sosial, fisik, maupun mental dan spiritual. Keberhasilan dan kegagalan tujuan pembangunan dapat ditentukan dan tergantung pada kualitas serta pembangunan sumber daya manusia sebagai modal utama dan pengelolaan pembangunan (Samsudin \& Ansori, 2013).

Pengembangan kualitas Sumber Daya Manusia (SDM) merupakan hal yang mendasar disamping sumber daya alam serta sumber daya ilmu pengetahuan dan teknologi. Pendidikan merupakan salah satu aspek yang memiliki peranan penting bagi pengembangan sumber daya manusia tersebut, sehingga pembangunan dapat berjalan dengan baik. Salah satu bentuk pendidikan yang dapat menunjang pengembangan sumber daya manusia tersebut adalah melalui Pendidikan luar sekolah. Ardiwinata dan Mulyono (2018) menjelaskan tentang tugas pendidikan luar sekolah yaitu : membelajarkan warga belajar agar mereka memiliki dan mengembangkan keterampilan, pengetahuan, sikap, nilai-nilai dan aspirasi untuk mengantisipasi pemungkinan perubahan di masa depan, dan membelajarkan warga belajar agar mereka mampu meningkatkan dan memanfaatkan sumberdaya alam guna meningkatkan taraf hidupnya.

Program pemberdayaan adalah pendidikan yang dapat memberikan bekal keterampilan yang praktis, terpakai, terkait dengan kebutuhan pasar kerja, peluangusaha dan potensi ekonomi atau industri yang ada di masyarakat (Saepudin \& Mulyono, 2019). Kampung Adat Cireundeu Cimahi merupakan desa yang memiliki sumber daya alam yang melimpah dan masih memegang teguh adat istiadat secara turun temurun yaitu salah satunya mengkonsumsi singkong sebagai makanan pokok.

Pembangunan masyarakat menyangkut upaya yang terencana dan terarah untuk meningkatkan kemampuan dan potensialitas anggota masyarakat, dan memobilisasikan antisiasme mereka guna berpartisipasi secara aktif dalam proses pengambilan 
keputusan yang menyangkut dirinya (Mulyono, 2018). Pembangunan masyarakat di Kampung Adat Cireundeu Cimahi lebih relevan pada pembangunan komunitas yang dilaksanakan dalam bentuk gerakan pembangunan pendidikan masyarakat.

Ruang lingkup pemberdayaan terhadap masyarakat di Kampung Adat Cireundeu Cimahi yang harus diberikan adalah:

1. Pemberdayaan kecakapan pribadi, yang terkait dengan. pengembangan potensi diri peserta didik secara menyeluruh. Kecakapan sosial, merupakan pengembangan kemampuan sosial terhadap masyarakat untuk mengenal untuk mengenal lingkungan hidupnya, cara bekerjasama, dan berkomunikasi yang baik.

2. Pemberdayaan kecakapan akademik, merupakan pengembangan kemampuan untuk menguasai ilmu pengetahuan dan teknologi yang berguna bagi produktifitas terhadap masyarakat.

3. Pemberdayaan kecakapan vokasional, penguasaan terhadap keterampilan berusaha sehingga membuka, mengelola usaha yang berupa produk barang maupun jasa untuk sumber kehidupan masyarakat menuju profesionalisasi profesi.

4. Melihat uraian penjelasan di atas penulis merasa tertarik ingin mengkaji lebih dalam lagi mengenai Pemberdayaan Untuk Meningkatkan Taraf Hidup Di Kampung Adat Cireundeu Cimahi.

\section{LANDASAN TEORI}

\section{Meningkatkan taraf hidup}

Meningkatkan taraf hidup dengan harta bisa didapatkan dengan cara bekerja keras, tapi tetap dalam lingkup pekerjaan yang halal untuk dapat meningkatkan kualitas hidup manusia, mulai dari kerja yang bersifat individu maupun kelompok atau juga wiraswasta, hingga bekerja kepada institusi pemerintahan yang berbasis negeri atau PNS seperti yang saya sebutkan dalam paragraf di atas (Karwati, Ansori \& Mulyono, 2018).

\section{Pembangunan masyarakat desa}

Pembangunan masyarakat desa adalah perpaduan antara pembangunan sosial ekonomi dan pengorganisasian masyarakat (Mulyono, 2012). Pembangunan sektor sosial ekonomi masyarakat desa perlu diwujudkan dalam program pembangunan organisasi dan partisipasi masyarakat yang tumbuh berkembang dari dan didalam kehidupan 
masyarakat dipandang sebagai lembaga pemicu pembangunan masyarakat pedesaan, dengan syarat organisasi masyarakat tersebut memiliki kapasitas, kapabilitas, dan performansi yang secara terus-menerus memperjuangkan kepentingan masyarakat. Kemiskinan dapat terlihat dari kondisi keluarga dan wilayah yang dihuni penduduk miskin. Gejala kemiskinan keluarga ditandai oleh rata-rata kelahiran dan kematian yang tinggi, angka pengangguran yang terus meningkat, tingkat pendapatan yang rendah, status gizi yang rendah, status perumahan yang kumuh, tingkat pendidikan yang rendah, pengeluaran konsumsi yang besar sementara pangan tidak mencukupi, sedangkan wilayah kemiskinan ditandai oleh pendapatan perkapita wilayah yang rendah, presentase rawan gizi yang tinggi. Disamping itu, kondisi pemukiman, transportasi, sarana air bersih jalan, fasilitas kesehatan, sarana pendidikan dan fasilitas umum lainnya yang tidak memadai (Samsudin \& Ansori, 2013).

\section{Kampung Adat Cireundeu Cimahi}

Cireundeu berasal dari nama "pohon reundeu", karena sebelumnya di kampung ini banyak sekali populasi pohon reundeu. pohon reundeu itu sendiri ialah pohon untuk bahan obat herbal. Maka dari itu kampung ini di sebut Kampung Cireundeu. Kampung Adat Cireundeu terletak di Kelurahan Leuwigajah, Kecamatan Cimahi Selatan. Terdiri dari 50 kepala keluarga atau 800 jiwa, yang sebagia besar bermata pencaharian bertani ketela. Kampung Adat Cireundeu sendiri memiliki luas 64 ha terdiri dari 60 ha untuk pertanian dan 4 ha untuk pemukiman. Sebagian besar penduduknya memeluk dan memegang teguh kepercayaan Sunda Wiwitan hingga saat ini. Selalu konsisten dalam menjalankan ajaran kepercayaan serta terus melestarikan budaya dan adat istiadat yang telah turun-temurun dari nenek moyang mereka.

Masyarakat adat Cireundeu sangat memegang teguh kepercayaannya, kebudayaan serta adat istiadat mereka. Mereka memiliki prinsip "Ngindung Ka Waktu, Mibapa Ka Jaman" arti kata dari "Ngindung Ka Waktu" ialah kita sebagai warga kampung adat memiliki cara, ciri dan keyakinan masing-masing. Sedangkan "Mibapa Ka Jaman" memiliki arti masyarakat Kampung Adat Cireundeu tidak melawan akan perubahan zaman akan tetapi mengikutinya seperti adanya teknologi, televisi, alat komunikasi berupa hand phone, dan penerangan. Masyarakat ini punya konsep kampung adat yang selalu diingat sejak zaman dulu, yaitu suatu daerah itu terbagi menjadi tiga bagian, yaitu: 
a. Leuweung Larangan (hutan terlarang) yaitu hutan yang tidak boleh ditebang pepohonannya karena bertujuan sebagai penyimpanan air untuk masyarakat adat Cireundeu khususnya.

b. Leuweung Tutupan (hutan reboisasi) yaitu hutan yang digunakan untuk reboisasi, hutan tersebut dapat dipergunakan pepohonannya namun masyarakat harus menanam kembali dengan pohon yang baru. Luasnya mencapai 2 hingga 3 hektar.

Leuweung Baladahan (hutan pertanian) yaitu hutan yang dapat digunakan untuk berkebun masyarakat adat Cireundeu. Biasanya ditanami oleh jagung, kacang tanah, singkong atau ketela, dan umbi-umbian.

\section{METODE PENELITIAN}

Metode pada dasarnya merupakan alat yang digunakan untuk mencapai sesuatu. Metode dapat diartikan sebagai cara untuk mencapai tujuan. Metodologi adalah proses prinsip dan prosedur yang kita gunakan untuk mendekati problem dan mencari jawaban Mulyana (2010:145). Dengan ungkapan lain metodologi adalah suatu pendekatan umum untuk mengkaji topik penelitian. Metode pendekatan yang digunakan dalam penelitian ini adalah pendekatan kualitatif metode deskriptif, metode ini dapat diartikan sebagai prosedur pemecahan masalah yang diselidiki dengan menggambarkan keadaan objek penelitian pada saat sekarang berdasarkan fakta-fakta atau apa adanya, metode deskriptif memusatkan perhatiannya pada menemukan faktafakta sebagaimana keadaan sebenarnya. Oleh karena itu dalam melakukan penelitian ini digunakan metode kualitatif disalah satu Desa Cireundeu Cimahi panentuan daerah penelitian dilakukan secara sengaja (purposive) dengan mewawancari 10 orang warga Desa Cireundeu Cimahi diantaranya pengusaha dan petani sebagai pelaku utama dalam penelitian.

\section{HASIL DAN PEMBAHASAN}

\section{Hasil}

Pendapatan masyarakat Desa Cireundeu Cimahi berkaitan erat dengan aktivitas usaha perekonomian, pertanian dan perkebunan serta usaha lainnya yang dilakukan oleh masyarakat dalam menunjang penghasilan mereka setiap hari. Peningkatan pendapatan masyarakat merupakan suatu kemampuan yang dimiliki oleh masyarakat melalui adanya peningkatan daya beli keluarga untuk membiayai kebutuhan sehari - hari 
keluarga baik kebutuhan dasar, kebutuhan sosial maupun kebutuhan lainnya yang terlihat dari peningkatan penghasilan keluarga, pengeluaran keluarga (kemampuan daya beli) dan perkembangan tabungan keluarga.

Upaya untuk meningkatkan pendapatan masyarakat melalui program pemberdayaan yang dilakukan antara lain, yaitu:

1) Bantuan pinjaman modal usaha melalui program nasional pemberdayaan masyarakat pedesaan.

2) Pengembangan motivasi bekerja dan berusaha pelatihan.

3) Pelatihan keterampilan usaha ekonomi.

Sementara itu, kegiatan pelatihan keterampilan berusaha berkaitan dengan program pelatihan yang dilakukan untuk mengembangkan maupun meningkatkan usaha yang berujung pada peningkatan pendapatan masyarakat. Program pelatihan memjadikan masyarakat memiliki pengetahuan dan keterampilan di bidang usaha, adanya peningkaan kemampuan dalam mengelolah dan menjalankan usaha serta peningkatan kemampuan dalam mengatasi berbagai permasalahan yang dihadapi dalam menjalankan usaha yang ada.

Hasil wawancara yang dilakukan pada 10 orang informan yang berasal dari unsur pemerintah, pelaku usaha/pedagang, petani dan tukang secara garis besar menunjukkan beberapa hal, yaitu :

1) Program pelatihan yang berhubungan dengan kegiatan peningkatan pengembangan usaha telah dilakukan oleh pemerintah melalui kegiatan pemberdayaan masyarakat desa.

2) Keikutsertaan masyarakat dalam program pelatihan dinilai oleh pemerintah dan lembaga keswadayaan masyarakat berhasil karena diikuti oleh masyarakat yang diundang.

3) Pemerintah selalu berusaha memotivasi masyarakat dengan memanfaatkan berbagai media baik melalui pengeras suara di desa, kegiatan sosial kemasyarakatan (dalam acara pernikahan, kedukaan, ibadah), maupun kegiatan lainnya yang banyak mengumpulkan masyarakat.

4) Memfungsikan perangkat kelurahan dalam memonitoring perkembangan usaha perekonomian masyarakat. 
5) Kegiatan penguatan modal usaha melalui pinjaman lunak dilakukan oleh lembaga keswadayaan masyarakat diterima langsung oleh masyarakat dan digunakan dalam pengembangan usaha.

6) Modal usaha yang diterima masyarakat cukup membantu usaha masyarakat dalam pengembangannya.

7) Kemajuan usaha selain berkaitan dengan penambahan modal juga berkaitan dengan area pemasaran komoditi.

8) Pendapatan masyarakat sangat berkaitan dengan usaha yang dilakukan serta hasil pekerjaan lainnya seperti gaji, hasil pertanian maupun peternakan.

9) Pengeluaran keluarga banyak berkaitan dengan kebutuhan hidup sehari hari, jumlah tanggungan serta kebutuhan lainnya seperti biaya pendidikan, biaya sosial maupun pengeluaran lainnya yang tidak terduga.

10)Dalam hal simpanan/tabungan oleh sebagian informan diakui dilakukan akan tetapi dalam hal aktivitas usaha perdagangan bahwa hasil keuntungan banyak difungsikan untuk menambahan modal usaha.

Pendapatan masyarakat baik meningkat maupun menurun secara nyata berhubungan erat dengan kebutuhan hidup dalam pemenuhannya. Sebagaimana pengakuan dari seorang informan bahwa yang bersangkutan cukup terbantukan dengan adanya bantuan pinjaman lunak dari kelompok swadaya masyarakat yang memberikan pinjaman untuk pengembangan usahanya. Akan tetapi diakuinya bahwa pemenuhan kebutuhan baik sandang, pangan maupun papan juga tidak dapat dihindarkan.

\section{Pembahasan}

Sehingga salah satu tindakan yang dilakukan adalah dengan menggunakan keuntungan usahanya untuk membiayai kebutuhan keluarga dalam hal pemenuhan konsumsi. Konsep pemberdayaan masyarakat sebagaimana teori dari Kartasasmita (1996:159160) yang mengemukakan tiga dimensi yang mempengaruhi pemberdayaan masyarakat yaitu :

1) enabling yaitu terciptanya iklim yang mampu mendorong berkembangnya potensi masyarakat.

2) empowering yaitu potensi yang dimiliki oleh masyarakat lebih diperkuat lagi dan,

3) protecting yaitu potensi masyarakat yang lemah dalam segala hal perlu adanya perlindungan secara seimbang agar persaingan yang terbentuk berjalan secara sehat. 
Dalam program bantuan keuangan, pemberian motovasi berusaha dan kegiatan pelatihan usaha membawa kecenderungan pada pemberdayaan masyarakat yang menekankan pada proses menstimulasi, mendorong atau memotivasi individu agar mempunyai kemampuan atau keberdayaan untuk menetukan apa yang menjadi pilihan hidupnya.

Pemikiran Kartasasmita (1996:159), dimensi enabling (kemampuan) merupakan upaya menciptakan suasana atau iklim yang memungkinkan potensi masyarakat berkembang (enabling). Disini titik tolaknya adalah pengenalan bahwa setiap manusia, setiap masyarakat, memiliki potensi yang dapat dikembangkan. Pemberdayaan adalah upaya untuk membangun daya itu dengan mendorong (encourage), memotivasi, dan membangkitkan kesadaran (awareness) akan potensi yang dimilikinya serta berupaya untuk mengembangkannya.

Menciptakan suasana atau iklim yang memungkinkan potensi masyarakat berkembang (enabling) diawali dengan dorongan bekerja keras yang dilakukan oleh pemerintah kepada masyarakat desa untuk bekerja lebih keras dalam rangka mencapai kemajuan masyarakat dan desa mereka sebagaimana motivasi dan kegiatan pelatihan yang dilakukan. Kerja keras akan mendorong terjadinya peningkatan produktivitas (hasil) kerja.

Selain itu ditanamkan pula keinginan yang kuat dari dalam diri masingmasing anggota masyarakat desa untuk lebih maju. Memotivasi merupakan upaya mendorong semangat seseorang dengan insentif atau bantuan sesuatu. Bisa untuk memenuhi kebutuhan sehari-hari, bisa juga berupa pemberian insentif uang atau barang untuk meningkatkan gairah kerja. Dimensi empowering yaitu memperkuat potensi atau daya yang dimiliki oleh masyarakat (empowering).

Dalam rangka ini diperlukan langkah-langkah lebih positif selain dari hanya menciptakan iklim dan suasana. Perkuatan ini meliputi langkah-langkah nyata dan menyangkut penyediaan berbagai masukan (input), serta pembukaan akses kepada berbagai peluang (opportunities) yang akan membuat masyarakat menjadi makin berdaya. Untuk itu perlu ada program khusus bagi masyarakat yang kurang berdaya, karena program-program umum yang berlaku untuk semua tidak selalu dapat menyentuh lapisan masyarakat seperti ini. Peningkatan pendapatan baik dalam hal 
usaha perdagangan, pertanian maupun peternakan memerlukan dukungan dari semua pihak termasuk ketersediaan sarana dan prasarana (Widiastuti \& Kartika, 2018).

Peningkatan pendapatan masyarakat merupakan bagian dari penyelenggaraan pembangunan dan pemerataan hasil - hasilnya kepada semua lapiran masyarakat tanpa terkecuali termasuk didalamnya pembangunan ekonomi masyarakat. Pemberdayaan masyarakat desa antara lain berkisar tentang bagaimana mengupayakan masyarakat desa dapat menjadi pelaku utama dalam pembangunan ekonomi serta dapat memanfaatkan sumberdaya secara optimal dan bertanggung jawab. Program bantuan keuangan non fisk memang tidak bisa langsung dilihat hasilnya, karena memerlukan proses panjang pembentukan perilaku, sikap, dan budaya masyarakat. Bisa saja dimulai dari tahap pengenalan, sosialisasi, pemberian contoh, pelatihan, penyuluhan, dan praktek lapangan (Rosita \& Ansori, 2019).

Pemberdayaan masyarakat desa menjadi berarti bagi peningkatan pendapatan antara lain berkisar tentang bagaimana mengupayakan masyarakat desa dapat menjadi pelaku utama dalam pembangunan ekonomi serta dapat memanfaatkan sumberdaya secara optimal dan bertanggung jawab dengan masyarakat mulai dan mempunyai daya kekuatan serta peningkatan kemampuan memanfaatkan potensi yang dimilikinya, termasuk memberikan penguatan internalisasi kapasitas kehidupan yang ada, baik pribadi maupun sosial (Fitriana \& Mulyono, 2019).

\section{KESIMPULAN}

Berdasarkan hasil penelitian dan pembahasan disimpulkan bahwa peningkatan Pendapatan Masyarakat Melalui Program Pemberdayaan di Kampung Adat Cireundeu Cimahi dilakukan melalui berbagai program pemberdayaan yaitu kegiatan bantuan pinjaman modal usaha melalui program nasional pemberdayaan masyarakat pedesaan, pengembangan motivasi bekerja dan berusaha pelatihan serta pelatihan keterampilan usaha ekonomi. Program pemberdayaan diarahkan pada :

1) enabling yaitu terciptanya iklim yang mampu mendorong berkembangnya potensi masyarakat

2) empowering yaitu potensi yang dimiliki oleh masyarakat lebih diperkuat lagi dan

3) protecting yaitu potensi masyarakat yang lemah dalam segala hal perlu adanya perlindungan secara seimbang agar persaingan yang terbentuk berjalan secara sehat 
sebagai upaya menjadikan masyarakat memiliki kemampuan dalam menjalankan usaha sehingga dapat meningkatkan pendapatan masyarakat.

\section{DAFTAR PUSTAKA}

Ardiwinata, J. S., \& Mulyono, D. (2018). Community Education in the development of The Community. EMPOWERMENT: Jurnal Ilmiah Program Studi Pendidikan Luar Sekolah 7 (1), 25-35.

Fitriana, W., \& Mulyono, D. (2019). IMPLICATION OF INTERNSHIP III PROGRAMS ON SOCIAL COMPETENCY OF SILIWANGI IKIP PENMAS STUDENTS. P2M STKIP Siliwangi 6 (1), 14-20.

Kartasasmita, G. (1996). Pembangunan untuk Rakyat: Memadukan. Pertumbuhan dan Pemerataan. Jakarta: PT Pustaka Cidesindo.

Karwati, L., Ansori, A., \& Mulyono, D. (2018). Women Empowerment to Build Entrepreneurship. Journal of Nonformal Education 4 (2), 169-176.

Mulyana, D. (2010). Metode Penelitian Kualitatif. Bandung: PT Remaja Rosdakarya.

Mulyono, D. (2014). Menegaskan Karakter Pendidikan Nonformal. Empowerment 1 (1), 63-68.

Mulyono, D. (2018). THE STRATEGY OF MANAGERS IN MOVING BUSINESS LEARNING GROUP PROGRAM IN PKBM SRIKANDI CIMAHI CITY. Journal Of Educational Experts (JEE) 1 (1), 41-50.

Rohaeti, E. E., Mulyono, D., Widiastuti, N., Ansori, A., \& Samsudin, A. (2018). "Rumah Paseban" as a Development Model for the Sustainability of the Equivalency Education Program. The 1st Inter-University Forum for Strengthening Academic Competency (IFSAC) (pp. 247-257). Bandung: Lemlit Unpas Press Universitas Pasundan.

Rosita, T., \& Ansori, A. (2018). Increasing Economic Capacity of Rural Community Through The Use of Local Ecological Potency Based. Journal of Nonformal Education 4 (1), 89-96.

Saepudin, A., \& Mulyono, D. (2019). Community Education In Community Development. EMPOWERMENT: Jurnal Ilmiah Program Studi Pendidikan Luar Sekolah 8 (1), 6573.

Samsudin, A., \& Ansori, A. (2013). TRANSFORMASI PEMBELAJARAN DI PENDIDKAN NON FORMAL (Upaya mempersiapkan pendidik dan peserta didik dalam menghadapi tantangan global untuk menjadi manusia pembelajar). EMPOWERMENT: Jurnal Ilmiah Program Studi Pendidikan Luar Sekolah 2 (1), 115.

Sugiyono. (2012). Metode Penelitian Kuantitatif, Kualitatif dan R\&D. Bandung: Alfabeta.

Widiastuti, N., \& Kartika, P. (2018). PENERAPAN MODEL KELOMPOK USAHA KREATIF ISLAMI (KUKIS) DALAM PEMBERDAYAAN PEREMPUAN BERBASIS PONDOK PESANTREN. Empowerment 6 (2), 20-29. 